\title{
Purpose of Education and Spiritual Potential; What is Your Definition
}

\author{
Indrawati Turmudia, Rohana Hamzah ${ }^{b}$, Sarimah Ismaila, Muhammad Afzamiman Aripina, Nor Hasrina Mohamad@Sulaiman,
} Haslinda@Robita Hashimc, Nur Qistina Andind

\author{
${ }^{a}$ Faculty of Education, University Teknologi Malaysia, 81310 UTM Johor Bahru, Johor, Malaysia \\ ${ }^{b}$ Pusat Bahasa Moden dan Sains Kemanusiaan, University Malaysia Pahang,26600 Pekan, Pahang \\ 'Pusat Kaunseling, UniversityTeknologi Malaysia, 54100 Kuala Lumpur, Malaysia \\ ${ }^{d}$ Faculty of Psychology and Education, Universiti Malaysia Sabah, 88400 Kota Kinabalu, Sabah,Malaysia
}

*Corresponding author: rohanahamzah@ump.edu.my

\begin{abstract}
Developing and producing a holistic human capital has been a major concern to Malaysian education system. Therefore, the National Education Philosophy has been formed based on a mission to produce a balance and holistic individual in terms of physical, emotional, spiritual and intellectual based on firm belief and devotion to God. In contrary, education system nowadays is more focused on intellectual and practical aspects, whereas spiritual dimension has being neglected. Spiritual dimension is taught separately in spiritual subjects and the responsibility to teach is given to the educators in the areas concerned. Needs analysis conducted on technical and engineering educators from three engineering faculty at UTM shows that majority of participants do not really understand the real purpose of education, the meaning of spiritual potential and also how spiritual potential can be developed through Technical and Engineering Education. Therefore, there is a possibility that this potential has been less developed through Engineering Education courses in UTM.
\end{abstract}

Keywords: Holistic; human capital; education; technical and engineering education; spiritual

(C) 2017 Penerbit UTM Press. All rights reserved

\subsection{INTRODUCTION}

Vision 2020 is a Malaysian ideal which was introduced by the former Prime Minister of Malaysia, Tun Mahathir Mohamad in 1991. The vision calls for the nation to achieve a self-sufficient industrialized nation by the year 2020 which encompasses all aspects of life from economic, social, educational, political as well as psychological balance (Retrieved November 28, 2011 from http://en.wikipedia.org). It also states the country's vision to become a developed nation on its own means. (Retrieved November 28, 2011 from http://pmr.penerangan.gov.my). This indicates Malaysia's aspiration to become a developed country in our own method without following the footsteps or patterns developed by other countries.

Malaysia's aim towards Vision 2020 has been sparked with the revolution of ideas by the following Malaysia's Prime Minister, Dato' Seri Abdullah Ahmad Badawi during his speech in Malaysia's Ninth Plan which emphasizes on developing human capital as a future generation platform of excellence. The future generation is seen as the most important asset of the country in its effort towards the realization of becoming a developed nation by the year 2020 (Retrieved November 28, 2011 from http://www.pmo.gov.my).

Since then, the development of high quality human capital becomes a priority in the National Mission. Human capital with ideal personality is described as an individual who is knowledgeable, confident with high moral values, ethical, courteous, disciplined, dynamic, innovative and creative. He should also possess leadership skills, which are to be fair, courageous and lead a healthy life. These human capitals are those who will determine the direction of the country in the future. (Retrieved November 28, 2011 from http://jpmportal.prison.gov.my).

As human capital development has become a major concern in the National Mission, National Higher Education Action Plan $2007-$ 2010 and the latest is 2015-2025 has also enhanced the transformation of higher education. These plans aim on the holistic human capital development in order to produce Malaysians "who are intellectually active, creative and innovative, ethically and morally upright, adaptable and capable of critical thinking". This plan will create the environment needed for the development of an individual to discover and fully attain his or her potential (National Higher Education Action Plan 2007-2010, 2007).

The higher education has to play a significant role towards the realisation of Vision 2020. Thus, higher learning institution must find a formula to develop a holistic human capital in its own distinctive approach. For this reason, we need to really understand the concept of the holistic approach in education before developing and integrating it into the education system particularly in Technical and Engineering Education.

Universiti Teknologi Malaysia (UTM) has become a leading university in engineering, science and technology in Malaysia. It is well known that the product of engineering and technological knowledge has contributed a lot to the technical and professional workforce in the country since 1904. It has the highest number of postgraduate enrolment in engineering and technology. UTM is also active in research activities. Thus, UTM"s effort has now bear fruit when it is given a title as Malaysia's premier research university in engineering and technology in 2010 (Retrieved August 27, 2010 from http://www.utm.my). 
Despite the fact that UTM has become a leading university in Malaysia, UTM still ranked at the 294 place in engineering and technology in the QS World University Ranking 2014/15 (Retrieved August, 2015 from www.topuniversities.com). This fact indicates that UTM is still struggling to transform its mission "to be a leader in the development of human capital and innovative technologies that will contribute to the nation's wealth creation" into reality. Furthermore, in order to pursue its vision "to be recognized as the world-class center of academic and technological excellence", UTM still has to put in lot of efforts to achieve its desired vision so as to achieve the Malaysian Vision 2020.

The strength of a higher learning institution is determined by the quality of its academic staff (Zaini, 2009). In other words, the main factor that contributes to the success of UTM in engineering and technology is the role of the educators who have continuously struggle to educate their students properly, professionally and ethically as engineers. By today, UTM had successfully produced quite a number of engineers who are not only working in Malaysia but also all over the world. In brief, the role of educators in technical and engineering education is very crucial to carry out UTM"s mission.

Generally, the technical and engineering educators have contributed a lot to the world. They have successfully produced many technical and engineering workforces for the development of the nation and the world. The knowledge and skills in Technical and Engineering Education have helped us to live in comfort and also realizing our dreams to land man on the moon. However, it also destroys our world in the name of development. Many countries try to compete with each other by building the most powerful and sophisticated weapon to show their superiority and power while some countries eagerly build the tallest building and skyscraper that can illustrate the skills and technology possessed by them. Development has been made often without mature consideration about other aspects for example the impact of social and environment sustainability will give an imbalance impact to the world.

The rapid development of the world within these fifty years has also change the structure of the society from an industrial society to an informational society. However, at the same time it causes the increase in crime rate, the failure of family institution, loss of trust, and the increase in selfish and individualistic society (Fukuyama, 1999). This is due to the education system that has been influenced by Western philosophies which have been developed separately from religion. As a result, education system has been producing large numbers of professional workforce but the standard of morality among them seems to be dropping (Wan Mohd. Zahid, 1994). The integration of religious value which is very important in teaching and learning process for developing good moral values has been abandoned (Tajul Ariffin \& Nor Aini, 2002). In fact, the supremacy and prosperity of a society is not determined by the industrial policy, but by their culture or the way of life of the society (Fukuyama, 1995 \& 1997).

Although Malaysia is an independent country, Malaysian education system is very much influenced by the former colonial country, Britain. The growth and development of higher learning institutions in developing countries are still influenced by the western country especially by the British as supported by Altbach (1982); Altbach \& Selvaratnam (1989). This can be seen in some aspects such as structures, roles, administrations and curriculums taught at higher learning institution (Altbach \& Selvaratnam, 1989). Even though religious or moral subjects are taught as a part of education curriculum, they separated from academic subjects that are prepared for students to the world of career. Therefore, there is less self-understanding on the application of religious values as a filter of good and bad in doing job in practical world.

Aligned with UTM's philosophy which is "the divine law of Allah is the foundation for science and technology, we are committed not to produce human capital that set aside their culture or religion. We want to produce engineers who develop technology yet contribute to the sustainability of the world. We also do not want to produce professional engineers who are also professional criminals. Thus, a balanced education system is very crucial. We need an education system that fits with our culture and educate our students with sense of responsibility to obey God's commands. We need to change and lead the changes to be better according to God commands not only to comply society or stakeholders needs. UTM as one of the higher learning institutions in Malaysia is expected to uphold and contribute towards the progress of a particular society and nation, especially in developing human capital for the country through technical and engineering education.

\subsection{THE PURPOSE OF EDUCATION AND THE ROLE OF UNIVERSITY}

The real purpose of education needs to be examined. Syed Muhammad Naquib stressed that education in Islam is not about to produce good human capitals and citizens only but to generate good persons. To him, a good human capital and citizens in a secular country is not the same with the concept of good person in Islam but a good person is surely a good human capital and citizen. A good person is viewed as a person who is fully aware of his responsibilities to God as a slave and caliph (leader), being fair to himself and others, strive to improve every aspect of himself towards perfection to become a good person (Wan Mohd. Nor, 2005).

Syed Muhammad Naquib also stressed that the real purpose of education is to produce a universal man (Wan Mohd. Noor, 2005). Universal man is a man who is not only an expert in a certain field of knowledge. A universal man is a man who is universal in his point of view and has the ability in several related field of knowledge (Wan Mohd. Noor, 2005) including religious knowledge because religious knowledge gives big impact to their thinking system. Man without a true system of thought that is based on the firm belief in One God, will think that they own the knowledge or skills or technology or world and tend to use what they have for their own benefit. This type of thinking system never produces man with justice consideration in mind when they ventured into the world of work. However, man who developed thinking system based on firm belief and devotion to Oneness of God will think that they own nothing and everything belongs to Allah. This type of thinking system wills develops sense of sharing, caring and responsibilities in their action. Throughout of history, Islam has produced quite numbers of universal man in the past such as Ibnu Sina, al-Khawarizmi, Ibnu Bajjah and many others who are an expert in various fields (Mohd Roslan, 2010). It is not enough for educators to know only one area of knowledge or discipline. Educators need to have interdisciplinary ability to enable them to clarify the knowledge globally (Hassan, 1997). In other words, universal man can be defined as a holistic person or a holistic human capital.

In education system, Syed Muhammad Naquib considered university as the most important institution in education system framework where revivalism in education begins. Therefore, the universities are the most suitable place for the implementation of the Islamic concept and be a model for the lower level in our education system. The universities are responsible at the final stage in shaping high quality human capital.

The University is also the place to improve any deficiency that happened in lower education. Any weakness or deficiency from previous education level should be recovered at the higher learning level. Therefore, the divine education should be planned and provided at this stage. 
The good and divine curriculum should aim to produce a good man, to guide new generation to define the real concept of God and to define the social responsibilities as a 'caliph' in developing relationship between knowledge, human beings, the society and the physical world. A good example of a holistic approach in education should be planned and provided at this level of education. A big revolution in our education system should begin with a small step within higher learning institution before spreading it out to the lower education level (Wan Mohd. Nor, 2005).

\subsection{SPIRITUAL POTENTIAL DEVELOPMENT THROUGH ENGINEERING EDUCATION}

It should be noted that Technical and Engineering Education is not only about engineering and educating future engineers only. It is about educating future engineer to become a good person and universal man that will contribute to the world development. Hence, the basic of Technical and Engineering Education should be made to be able to prepare technicians and engineers that know their own self and their responsibilities towards their God, being fair to other human being and to all God's creation in the world (Indrawati, Rohana, Sarimah, Sukri \& Qistina Andin, 2010). Thus the roles of engineering educators are very important to shape what kind of engineers that education system are going to produce. However, engineering educators need to develop themselves holistically first before developing their students.

Therefore, intellectual and spiritual development should be hand in hand and complement each other. It can be achieved through holistic self- development education approach. The holistic self-development approach is a foundation made to develop our self by knowing who we really are and the reasons for our existence which is termed as self-actualization. Syed Muhammad Naquib defined self-actualization as man"s awareness of his personal fact and ultimate goal in life (Wan Mohd. Nor, 2005). If students are not certain of who they really are, it will be challenging for them to pursue intellectual inquiry (Haynes, 2006). In brief, by knowing our self, we will achieve more in this life. However, education system today is more focused on intellectual, physical and emotional aspects only while spiritual dimensions are being neglected. Spiritual aspects are taught separately in spiritual subjects and the responsibility to teach it is given to the educators in the areas concerned. Besides, our education systems nowadays have become more obsessed with acquisition and achievement (Miller, 2005).

While, according to Rohana and Kamarudzaman (2010), spiritual potential development is the starting point in human development process which focuses on self-awareness about self-actualization and purpose of life. This is because men are made from two elements which are body (physical) and soul (spiritual). Basically, each human being has two roles towards God; first, as a slave to Him and second, as His caliph. As His caliph, man is responsible toward himself, others and also the physical world. Man who knows himself and his responsibilities will be able to develop himself as a good human, being that, he will contribute to the wellness of the community and the physical world.

Thus, Rohana (2010) modified Maslow Hierarchy of Needs by turning the pyramid upside down and adding new element to it. Human development process started with spiritual development that is self-actualization, followed by actualization about self-responsibilities, social responsibilities and lastly to fulfil responsibilities toward physical world. All four levels are driven by love for God, for people and the whole universe. This model as shown in Figure 1, is developed so that education is able to develop human being holistically in education process to produce more and better human beings who have true system of thought.

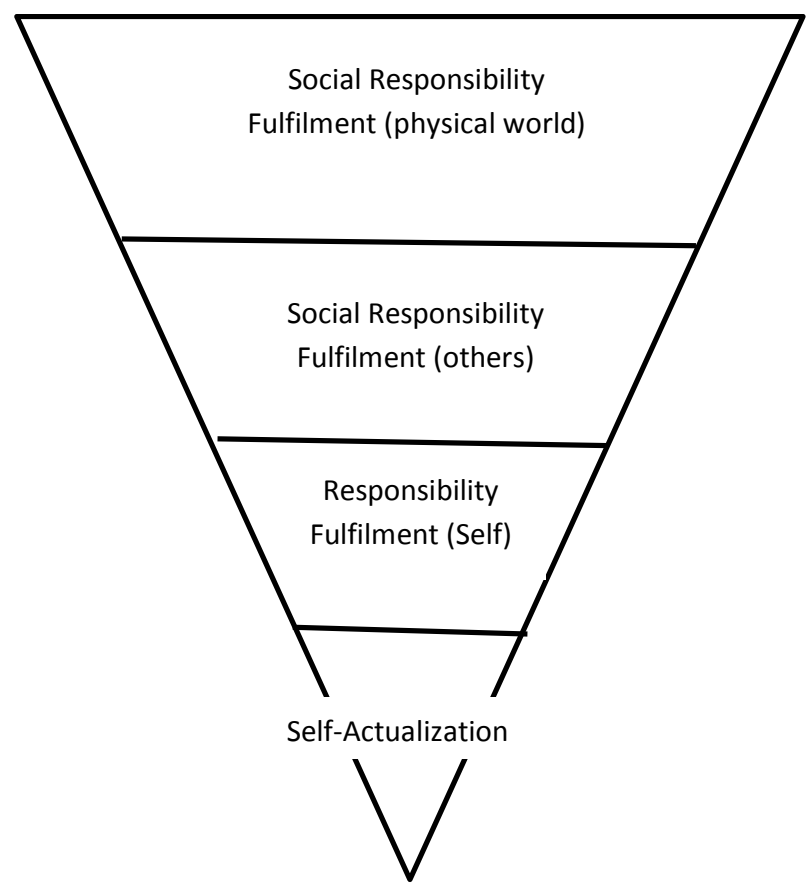

Figure 1 Maslow upside-down (Rohana, 2010)

In line with Vision 2020, which has aspired Malaysian to develop the nation in our own method, we need to make a transformation or improvement to our educational system. In order to produce holistic human capitals in technical and engineering field, we need to produce holistic technical and engineering educators in the first place. Only holistic educators will produce holistic students (Rohana, 2010) or holistic 
human capitals. So, the transformation here means the self-development of technical and engineering educators by using the holistic approach based on Islamic philosophy to become holistic educator in line with UTM"s philosophy that is:

"The divine law of Allah is the foundation for science and technology. UTM strives with total and unified effort to attain excellence in science and technology for universal peace and prosperity in accordance with His will"

(Retrieved Mac 28, 2015 from http://www.utm.my)

UTM's philosophy clearly states that the divine law of Allah is the foundation for science and technology. In other words, the reveal knowledge becomes the foundation to the development of intellectual knowledge. This approach aims to develop the students ${ }^{\text {ee }}$ souls through intellectual knowledge and to ensure they are aware of God's existence as the key for spiritual potential development and realise the purpose of their life as a caliph on this earth as the main reason for developing social responsible in their career as engineers in future. Thus, the holistic approach which integrates reveal knowledge with intellectual knowledge is parallel with UTM"s philosophy.

\subsection{PROBLEM STATEMENT}

In Islam, educators' role is very important. Students are reminded not to rush to learn from any teacher but advised to take their time to choose the best teacher in the field they would like to learn (Wan Mohd. Nor, 2005). Educators claimed to have the ability to think globally and holistically, but at the same time are able to be fully in touch with the core values of local culture. Educators should also be ready to play their role as a muallim, murabbi, leader, and dynamic change agents simultaneously (Azhar \& Zawawi, 2009). The high quality educator aspired by the nation is the educator that performs his duties and responsibilities as a caliph (leader) and as servant to God. Only with this kind of awareness, educators will be able to put effort to bring about changes to produce good human being (Azhar \& Zawawi, 2009). Therefore, it is crucial for educators in the Technical and Engineering Education to develop them holistically in the first place before trying to develop their students.

There are very little research which have been done from Islamic perspective of self-development in Technical and Engineering Education. Thus, the general concern of this study is to identify the purpose of engineering education and meaning of spiritual potential as understood by engineering lecturer.

The objectives research objectives are:

i. To identify the technical and engineering educators' understanding about the purpose of engineering education

ii. To identify the technical and engineering educators' understanding about spiritual potential

\subsection{RESEARCH METHODOLOGY}

The design of this research was in qualitative form where researcher used interview technique as a main method to get hold of the data. Interview method used was structured interview that contained a list of questions which had been prepared in advance and then during interview, the interviewer (researcher) recorded the answers given by interviewee (participant) (Mohd. Najib, 1999). Data obtained was based on their past experience and understanding about spiritual potential.

Research population chosen consists of senior lecturers from Faculty of Mechanical Engineering (FKM), Faculty of Geoinformation and Real Estates (FKSG) and Faculty of Chemical Engineering (FKChE). The total population is 189. Purposive random sampling was used as sampling technique. According to Patton (1990), the advantages of using purposive sampling lies in the selection of information-rich cases for study in depth. Thus, this type of sampling procedure is suitable to the qualitative method. Through this technique, a random of $15 \%$ ( 29 out of 189) was selected from the whole population (Lodico, Spaulding, \& Voegtle, 2006) with the consent of participants.

The researcher used 6 common steps to analyse qualitative data. The steps are preparing and organizing data, reviewing and exploring data, coding data into categories, constructing descriptions of people, places and activities, building themes and testing hypotheses and finally reporting and interpreting data (Lodico, Spoulding \& Voegtle, 2006).

\subsection{CONCLUSION}

The accumulated data has been analyzed using qualitative method and tabled to abstract and summarize the idea.

Table 1 shows the findings from the first interview question which asked participants' respond on the purpose of Technical and Engineering Education. The findings show that most participants have more than one opinion about the purpose of Technical and Engineering Education 
Table 1 The purpose of technical and engineering education

\begin{tabular}{|c|c|c|c|c|c|c|c|c|c|c|c|c|c|c|c|c|c|c|c|c|c|c|c|c|c|c|c|c|c|}
\hline No & Code & R1 & $\mathrm{R} 2$ & $\mathrm{R} 3$ & $3 \mathrm{R}$ & $4 \quad \mathrm{R}$ & $\overline{\mathrm{R} 5 \mathrm{I}}$ & R6 & R7 & R8 & R9 & $\begin{array}{l}\mathrm{R} \\
10\end{array}$ & $\begin{array}{l}\mathrm{R} \\
11 \\
\end{array}$ & $\begin{array}{l}\mathrm{R} \\
12\end{array}$ & $\begin{array}{l}\mathrm{R} \\
13\end{array}$ & $\begin{array}{l}\mathrm{R} \\
14\end{array}$ & $\begin{array}{l}\mathrm{R} \\
15\end{array}$ & $\begin{array}{l}\mathrm{R} \\
16\end{array}$ & $\begin{array}{l}\mathrm{R} \\
17\end{array}$ & $\begin{array}{l}\mathrm{R} \\
18\end{array}$ & $\begin{array}{l}\mathrm{R} \\
19\end{array}$ & $\begin{array}{l}\mathrm{R} \\
20\end{array}$ & $\begin{array}{l}\mathrm{R} \\
21\end{array}$ & $\begin{array}{l}\mathrm{R} \\
22 \\
\end{array}$ & $\begin{array}{l}\mathrm{R} \\
23 \\
\end{array}$ & $\begin{array}{l}\mathrm{R} \\
24 \\
\end{array}$ & $\begin{array}{l}\mathrm{R} \\
25 \\
\end{array}$ & $\mathrm{f}$ & $\%$ \\
\hline 1 & $\begin{array}{l}\text { To transfer } \\
\text { knowledge and } \\
\text { skills }\end{array}$ & I & I & I & I & & & & / & I & I & / & / & / & & / & / & & & / & & / & & & & & / & 14 & 56 \\
\hline 2 & $\begin{array}{l}\text { To produce } \\
\text { engineers/graduates }\end{array}$ & & & & I & / & & I & & & & I & & I & / & & & & I & & I & & & / & / & / & & 10 & 40 \\
\hline 3 & $\begin{array}{l}\text { To meet industrial/ } \\
\text { national needs }\end{array}$ & & I & I & / & & & I & & & I & & & & & & & & & & & & I & & & & & 6 & 24 \\
\hline 4 & $\begin{array}{l}\text { To improve life/ } \\
\text { make decision }\end{array}$ & & & & & & & & & & I & & & & & & & I & & & & & & & & & & 2 & 8 \\
\hline 5 & $\begin{array}{l}\text { Fardhu ain/ fardhu } \\
\text { kifayah }\end{array}$ & & & & & & / & & & & & & & & & & & & & & & & & & & & & 1 & 4 \\
\hline 6 & $\begin{array}{l}\text { To meet } \\
\text { university's mission }\end{array}$ & & & & & & & & & & & & & & & & & & & & & & I & & & & & 1 & 4 \\
\hline 7 & $\begin{array}{l}\text { To produce } \\
\text { universal man }\end{array}$ & & & & & & & & & & & & & & & & & & & & & & & & & & & 0 & 0 \\
\hline 8 & $\begin{array}{l}\text { To produce good } \\
\text { human being with } \\
\text { self-awareness as a } \\
\text { leader with sense of } \\
\text { slave to God }\end{array}$ & & & & & & & & & & & & & & & & & & & & & & & & & & & 0 & 0 \\
\hline
\end{tabular}

Based on Table 1, majority of participants (56.00\%) view that the purpose of Technical and Engineering Education is to transfer knowledge and skills in engineering field. The few examples of participants statements are as shown below.

"tujuan technical and engineering education ini adalah memberikan ilmu dan kemahiran kepada... mahasiswa atau pelajar dalam..dalam bidang teknologilah secara umumnya.."

"mainly the purpose of education that is to provide them with skill and knowledge needed in the field..their respective field."

"Mendidik manusia celik pendidikan teknikal dan kejuruteraan"

"Pendidikan kejuruteraan... tujuan...untuk memindahkan ilmu teknologi terkini..."

"Untuk memberi pendedahan kepada mereka dari segi ..aaa... konsep-konsep kejuruteraan yang asas la..supaya bila diorang kerja nanti diorang boleh apply dalam diorang punya pekerjaan la..."

"kemahiran, pengetahuan macam mana nak buat dia...exposure dia..."

Besides transferring knowledge and skills in the technical and engineering field, $40.00 \%$ of participants felt that other purpose of Technical and Engineering Education is to produce engineering graduates or future engineers. Some of the participants such as R17 and R23 even specified the characteristics of the engineers that have the calibre and ethics. Few examples of respondent's response are shown as the following statement:

"untuk melahirkan engineer yang berkaliber..good knowledge in engineering..engineering background..."

"Pertamanya untuk tambahkan bilangan engineer la kan...bilangan yang engineer... yang berkurang dengan industry yang berkembang je...jadi salah satunya..kita nak cari lagi tenaga-tenaga baru...engineer-engineer baru...”

$24.00 \%$ of participants think that the purpose of technical and engineering education is not only transferring knowledge and skill in engineering field in order to produce engineers but also to meet the industrial and national needs. This type of thinking has been influenced by Pragmatism education philosophy. Based on Pragmatists thinker purpose of education is to develop students' character development based on making group decisions in this case it is refer to industries (Cohen, 1999), not universal needs as command by God.

"sebab kita perlukan kepada kemahiran teknikal dan kejuruteraan because itu adalah salah satu factor yang membantu membangunkan sesebuah negara lah..."

"Just to provide technical know-how, technical knowledge plus some job requirement needed by industry... which they could fulfil."

“...build up the country..that can contribute to the... kata orang tu.. err... ke arah er.. Negara maju..that we are..aa... targeted to be... err.. developed country in 2020.”

“... yang dapat memenuhi keperluan Negara...aa..itu lah...masa kini dan masa depan..”

“...sebab apa keperluan industry itulah yang kita penuhi...” 
The remaining participants of R5, R16, and R12 have their own opinions about the purpose of Technical and Engineering Education such as the need to meet the demands of Fardhu Ain and Fardhu Kifayyah (4.00\%), to improve live or simplify life through engineering technology $(8.00 \%)$ and to realize the vision, mission and objectives of the university $(4.00 \%)$.

"Pada pandangan saya laaa ni...fardu ain..fardu kifayyah bagi saya..we should fulfilled this..if this is not fardu ain..it is fardu kifayyah..somebody has to do it......"

“...untuk improvekan.. kita punya.. life .. apa ni life punya kehidupan kita kan...untuk especially in engineering..tujuan kita..kita design something untuk improve life...atau untuk simplify life punya keadaan.. berkaitan dengan engineering.. yang kita buat kat sini mechanical engineering..."

"pendidikan kejuruteraan pada saya.. dia aa... berlandaskan kepada misi dan visi university tu sendirila la... tapi dalam masa yang sama ..kita tak boleh hanya ada atau tujuan sahaja...kita kena ada variasi dalam kita punya objektif.. contohnya.. macam UTM sekarang ni menekankan tentang research.. errrmm.. finding new knowledge...aaa....lepastu kita dapat satu design yang baru lepas tu kita patentkan...kita publishkan sharing knowledge amongst academics all around the world la..."

The overall analysis of the data for the first interview questions indicate that most participants view that the purpose of Technical and Engineering Education is to transfer knowledge and skill to produce engineers that will meet the industry requirement and develop the nation. None of the participants mentioned directly anything about the production of universal men who are experts in several related field of knowledge and the production of good human beings with self-awareness as a leader (caliph) of changes with sense of slave to God through education process. However, there is $4.00 \%$ (one respondent) which shows self-understanding about the purpose of human development though Engineering education which is to be responsible in fulfil man's responsible in fardhu ain and fardhu kifayyah.

Based on literature review in Chapter 2, $80.00 \%$ of participants can only give less accurate answers for the question given. They only know some of spiritual potential characteristic in general but not in specific. $20.00 \%$ of participants admit that do not understand or not very sure about what is meant by spiritual potentials. Some even assume generic skills or soft skills as spiritual potential which is absolutely different. Overall, none of the participant gave the accurate answers about what spiritual potential is.

Based on literature review in Chapter 2, Technical and Engineering Education is the activity of teaching or transferring knowledge and principles associated to the professional practice of engineering (Retrieved December 12, 2011 from http://en.wikipedia.org). The learning is required by students to become successful engineers and technical expertise (Crawley, Malmqvist, Ostlund, et. al. (2007). This statement is based on secular education system which has been inherited since the colonial era.

As a result, the ideas of secular education system still have influence in our education system nowadays. Based on research finding on need analysis, majority of participants believe that the purpose of Technical and Engineering Education is to transfer knowledge and skills to produce engineers required by industry and nation. Their statement is aligned with what is mentioned by Zaini (2009) that almost all higher institutions are focusing more on the development of academic programs that are related to the demands of job market. Most universities have become a factory to produce graduates as much as possible in order to fulfil the market's or stakeholders' demand.

Some of participants also added that the purpose of Technical and Engineering Education is to produce good human capital or engineers who have ethics. Their opinion is also parallel to Zaini (2009) who stated that university should function as an institution responsible to develop human capital with first-class mentality and cultivate knowledge. The answer given is correct but Syed Muhammad Naquib once stressed that education in Islam is not about to produce good human capitals only but to generate good persons. Good human capital in a secular country is not the same with a good person, but a good person is surely a good human capital. A good person is viewed as a person who is fully aware of his responsibilities toward his God, being fair to himself and other living being, strive to improve every aspect of his self toward perfection to become a good person (Wan Mohd. Nor, 2005). Thus, a good technician or engineer is not the same with a good person. Only good person will be a good technician or engineer.

In addition, Syed Muhammad Naquib also pointed out that the real purpose of education is also to produce universal man (Wan Mohd. Noor, 2005)

Universal man is a man who is not an expert in a certain field of knowledge only. A universal man is a man who is universal in his point of view and has the ability in several related field of knowledge (Wan Mohd. Noor, 2005) including religious knowledge.

Islamic civilization has produced quite numbers of universal man in the past such as Ibnu Sina, al-Khawarizmi, Ibnu Bajjah and many others who are an expert in various fields of knowledge (Mohd Roslan, 2010). It is not enough for educators to know only one area of knowledge or discipline. Educators need to have interdisciplinary ability to enable them to clarify the knowledge globally (Hassan, 1997). In other words, universal man can be defined as a holistic person or holistic human capital. Thus an engineer must develop themselves to be a universal man who is competent both in engineering and several related knowledge including religious knowledge.

Table 2 shows the findings from the second interview question which asked participants' respond on the meaning of spiritual potential. 
Table 2 Meaning of spiritual potential.

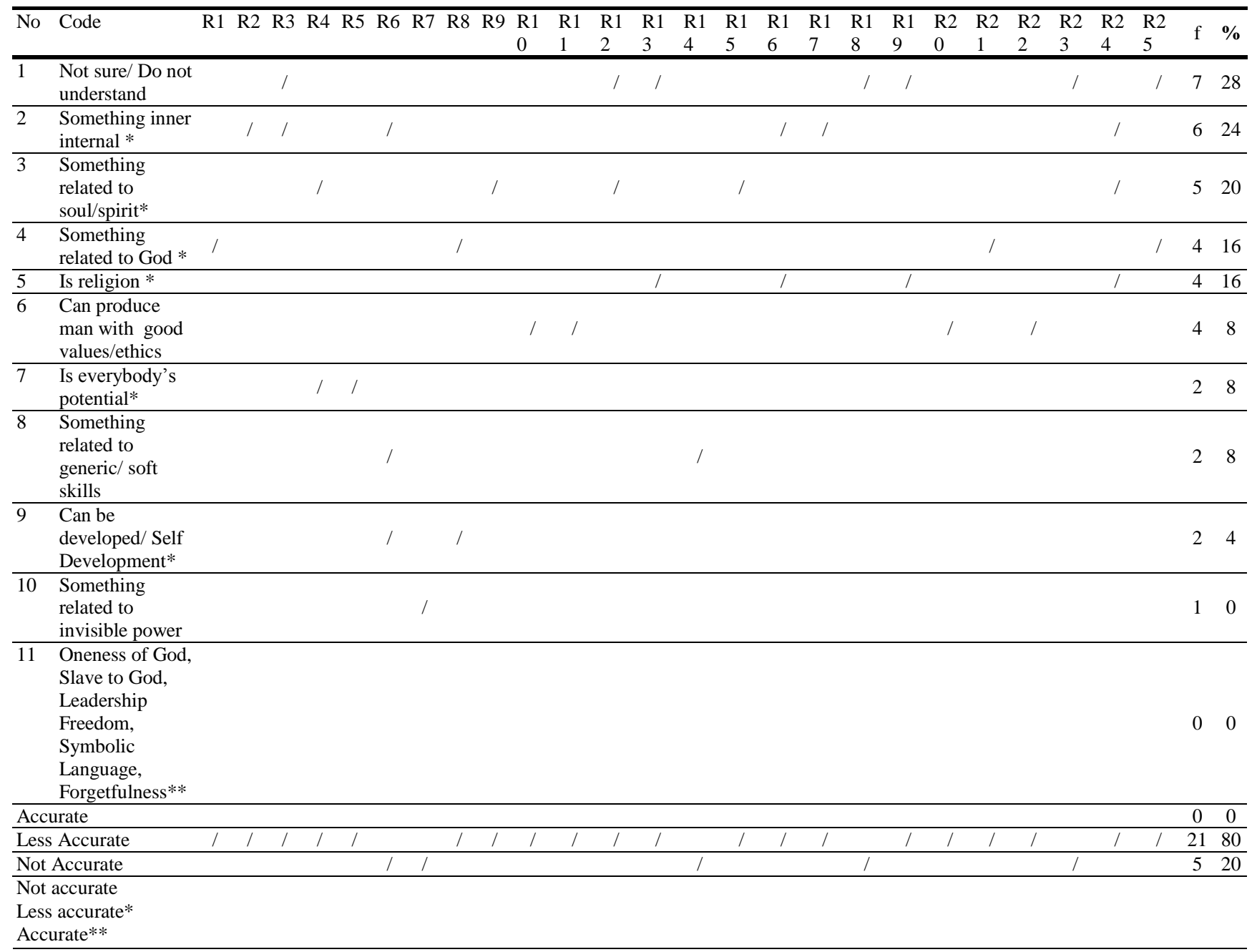

Even though that there are many reactions and questions arise due to the unexpected questions, some of participants still tried to guess or illustrate roughly about spiritual potential from the words spiritual and potential itself. 24.00\% participants of R2, R3, R6, R16, R17 and $\mathrm{R} 24$ relate it to something inner or internal.

"aaaa...it has something to do with your inner self kot.<guessing>"

“.. ni spiritual ni lebih kepada penghayatan dalaman kot..<guessing >”

“. dia bukan ..dia bukan kemahiran yang kita boleh nampak.. tapi dia lebih daripada dalaman"

"As a muslim saya bayangkan something yang related dengan Islam la... dari segi agama..ataupun benda-benda yang batiniah.. bukan yang lahir..."

“Aaa....kalau saya tengok dari term yang digunakan..i can assume as dalaman punya....."

Some participants understand spiritual is something related to soul or spirit (20.00\%). Meanwhile, others relate spiritual to God and religion (16.00\% respectively) but they don't have idea how can spiritual potential be developed through engineering course. One respondent can describe clearly how he related his subject to God. Below are the statement regarding to their understanding about spiritual potential.

"rohani tu i think is spiritual la"

"dari segi kerohanian dia la maknanya kan... “

“... benda yang tak nampak kan? Okay... tulah Bila nampak spiritual ni...macam kerohanian la... tapi tak berapa nampak macam mana nak link kan dengan kejuruteraan...”

"Spiritual is something which is a...rohani..." 
“Aaaa...Because perkataan spiritual tu maknanya kita...pada saya..kemampuan keupayaan pelajar tu mengambil nilai..atau neracanya based on...bukan setakast aa.. yang biasa saja tapi maknanya dari segi kehendak ..aa...spiritual tu ..dia answerable kepada kuasa yang lebih besar daripada dia..maksudnya bukan boss maksudnya maknanya Tuhanlah.. pada saya tu maksudnya spiritual potential maknanya yang boleh memotivasikan dia berdasarkan something yang ghaib...termasuklah of courselah.. we are talking about Tuhan..

“:As a muslim saya bayangkan something yang related dengan Islam la... dari segi agama.."

"katakan lets say...kita ajar tentang sesuatu benda....bendanya pasal..aaa.. apa-apa material la kan...so kita kena relatekan balik dengan Tuhan... dengan Allahla... yang mencipta benda ni."

$8.00 \%$ of participants do believe that spiritual potential is everybody's potential and $16.00 \%$ also believes that spiritual potential will produce man with good values and ethics. While, $16.00 \%$ believe that spiritual potential can be developed.

"basically every newborn...sebagai seorang yang macam you kata la.... berpotensi dari segi spiritual..."

"saya rasa semua orang ada keupayaan spiritual..sebab Allah jadikan semua orang itu..aaa.. sama la kan..bersih kann"

“....apa yang boleh dikembangkanla untuk masa depan..."

“.. mengukuhkan lagi dia punya kepercayaan dan potensi untuk terus berjaya.... kira..self-development..la...”

R10, R11, R20 and $22(16.00 \%)$ believe that spiritual potential can help to produce man with good values and ethics.

"Sebagai seorang jurutera dia mestilah jujur ikhlas dan apa-apa yang dia buat mestilah bertanggungjawab kepada keselamatan dan nyawa manusia.."

“...potensi spiritual ni nak terap nilai-nilai murni laa...”

"Potensi spiritual..agar pelajar itu menjadi amanah la dalam menjalankan tugas mereka...." spiritual ni sangat luas dan ia mempengaruhi tingkah laku kita."

Besides above statement, there are also some participants who assumed that spiritual potential is soft skills or generic skills. "Potensi spiritual ni aaa...ada saya..lebih merujuk kepada generic skill...lah"

Based on general finding, some engineering educators have the tendency to ignore spiritual aspect. This is proven when some of the participants are not able to answer the questions about spiritual potential. They seem quite surprised to the question given. This is due to their misunderstanding on spiritual aspects. Spiritual aspects and intellectual aspects are seen as two separate entities. Thus, it limits them to see the relationship between engineering education and spiritual aspect as a whole.

Spiritual potential refers to man's hidden or internal potential. Human spiritual potential according to Rohana (2010) is consciousness and strongly belief in God as the only Creator of the whole universe. In order to develop spiritual potential which is belief and devotion to God, man has to be guided to use his conscience. Furthermore, they have to be assisted to use the power of freedom and their ability to understand symbolic language to get the right concept of God. As a result, they can develop internal control to have power over their bad desire. At the same time man has to be reminded that they are forgetful, so that they will never reach their perfection and need to learn and re-learn. Therefore, spiritual potential is another domain that should be focused and developed throughout engineering education.

\subsection{CONCLUSION}

Overall, research findings on the purpose of technical and engineering education have been narrowed down by participants to simply producing sufficient technicians and engineers as needed by industries for the nation. This is due to the fact that technical and engineering educators do not really understand the meaning of education and the meaning behind national philosophy of education in depth. Development of balance human being in intellectual, physical, emotional and spiritual is done separately. They are more focused on intellectual, physical and emotional only and less attention to the spiritual aspect. This statement is supported by Miller (2005).

From the finding, it has been shown that almost all technical and engineering educators do not seem to really understand about spiritual potential. Majority of participants chose to say that they are not sure or do not understand what is spiritual potential is all about. However, there are minority of participants who assume generic skills as spiritual potential which is totally incorrect. Generic skills defined by Australian Chamber of Commerce Industry and Business Council of Australia (2002) as skills required to gain employment and to progress to achieve one's potential and contribute to enterprise strategic direction. In short, generic skills are closely related to employability purpose. For that purpose, they have to contribute and use their skill to make sure that they can get and stay on the job. Meanwhile, spiritual potentials are more than that. Spiritual potential involves divine concept in every aspect of life which has broader purpose to guide man in their principle of life for self-empowerment, decision making skills, have a great impact on their social skill as well as on their self-development to succeed in their future. Moreover, the purpose of life that integrates well through engineering education will become internal motivation for them to be successful in their career as an engineer. 


\section{References}

Altbach, P. G. (1982). Higher education in the Third World: Themes and Variations. Singapore: Maruzen Asia Pte. Ltd.

Altbach, P.G. \& Selvaratnam, V. (Eds.) (1989). From Dependency to Autonomy: The Development of Asian Universities. London: Kluwer Academic

Crawley, E., Malmqvist, J., Ostlund, S., and Brodeur, D. (2007). Rethinking Engineering Education: The CDIO Approach. New York: Springer.

Cohen, L.N.M., (1999). Philosophical Perspective in Education. OSU: School of Education, http://oregonstate.edu/instruct/ed416/PP2.html

Fukuyama, F. (1995). Trust the Social Virtues and the Creation of Prosperity. New York: The Free Press.

Fukuyama, F. (1999). The Great Disruption Human Nature and the Reconstitution of Social Order. London: Profile Books.

Fukuyama, F. (1997). Sifat Unggul dan Kemakmuran. Pemikir. Jan-Mac (7), 1-15.

Hassan Ahmad (2006). Ke Arah Kelahiran Melayu Glokal Memperkasa Bangsa Melalui Kekuatan Dalaman. Shah Alam: Alaf 21 Sdn. Bhd.

Haynes, C. (2006). The Integrated Student: Fostering Holistic Development to Advance Learning. About Campus, 10, 17-23.

Indrawati Tumudi, Rohana Hamzah, Sarimah Ismail, Sukri Saud and Qistina Andin Abdullah. Re-engineering Basic of Engineering Education Toward Sustainable Development: A Holistic Approach. Proceedings of the 2010 International Conference in Islamic Education. November 29-December 1, 2010. Selangor: Secretariat ICIEd. 2010. 939-944.

Lodico, M. G., Spaulding, D. T., Voegtle, K. H. (2006). Methods in Educational Research: from Theory to Practise. San Francisco: Jossey-Bass

Miller, J. (2001). The Holistic Curriculum. Toronto: OISE Press.

Miller, J. P. (Ed.) (2005). Holistic Learning and Spirituality in Education: Breaking New Ground. New York: State University of New York Press.

Mohd Roslan Mohd Nor (2010). Meneladani Sejarah Umat Islam dalam membentuk Masyarakat. Jurnal Hadhari, 2(2), 19-40

Mohd. Najib Abdul Ghafar (1999). Penyelidikan Pendidikan. Skudai: Penerbit Universiti Teknologi Malaysia.

Mohd. Najib Abdul Ghafar. (2003). Reka Bentuk Tinjauan: Soal Selidik Pendidikan. Skudai: Penerbit Universiti Teknologi Malaysia.

Rohana Hamzah (2010). Mengenali Manusia: Asas Pembangunan Pendidikan Berkualiti. Johor: Penerbit UTM Press.

Rohana Hamzah and Kamarudzaman Md. Isa. The Effectiveness of Interactive Multimedia Courseware in Developing Student"s Self-enlightening Level. Jurnal Teknologi.2010. 52. 29-43.

Tajul Ariffin Noordin and Nor Aini Dan (2002). Pendidikan dan Pembangunan Manusia: Pendekatan Bersepadu. Bangi Selangor: As-Syabab Media.

Wan Mohd Zahid Wan Mohd Noordin (1994). Wawasan Pendidikan Agenda Pengisian. Kuala Lumpur: Cahaya Pantai Publishing (M) Sdn. Bhd.

Wan Mohd. Nor Wan Daud (2005). Falsafah dan Amalan Pendidikan Islam; Syed Muhammad Naquib Al-Attas: Satu Huraian Konsep Asli Islamisasi. Kuala Lumpur: Penerbit Universiti Malaya.

Zaini Ujang (2009). The Elevation of Higher Learning. Johor: Penerbit Universiti Teknologi Malaysia. 